\title{
The Local Cultural Values In The Interaction Of Matematics Learning At School
}

\author{
Irwan Akib \\ Department of Mathematics, University of Muhammadiyah Makassar
}

\begin{abstract}
Abstrac: This research is an interdisciplinary study that aims to examine the cultural values of Bugisi Makassar which is involved in the interaction of the mathematics learning. This research was done at one of the schools in the city of Makassar by recording anecdotal for observing and analyzing the interactions that occur between teachers and students and also between students and students. The important recording is observing the cultural values of Bugisi Makassar that is involved in the interaction process. The result of this research shows that the dual concepts of the culture of bugis Makassar are siri' and pacce that is involved in the interaction of mathematics learning process between the interaction of teacher and students and also between students and students. This research also shows that in the interaction between teacher and students, the teacher always gives a motivation to students so they can get a good achievement. It is the realization of the siri' cultural value, as well as the students, are competing and trying to do their projects as well. Another result that related with the value of pacce is reflected in the teacher effort to help the students who have a difficulties and also a problem with their academic. So, the cultural values of siri and pacce as the main concept in the culture of Bugis Makassar
\end{abstract}

Keywords: Interactions, Siri', Pacce

\section{Background}

The teaching and learning activities require a positive interaction between teacher and students, and also the students and student. The interaction is not only about how the teacher convey the material to students, but interaction requires students' understanding of humanely. Cobb, Wood, \& Yackel (1991) states that mathematics classroom can be viewed as a social context in understanding of mathematics which a way of construction and negotiation. Thus, Atweh, Bleicher \& Cooper (1998) reveals that the mathematics classroom is a place of teacher and students to build the interactive social environment, with the main goal of enhancing the teaching process. The other side of students who are studying in schools, they also has own character from their surroundings as the socialization process, including socio-cultural factors.

The mathematics learning in schools is expected to establish the logical reasoning and attitude of students, and also to extend the supplies of students to implement the mathematics in their daily life. Soedjadi (1999) stated that teaching mathematics in every level of schools is basically referred for two main purposes, which are the formal purpose and the material purpose. The formal purpose of mathematics is relating of structuring the logical reasoning and the attitude of students, whereas the material purpose of mathematics is relating to the uses of mathematics, in the field of mathematics itself or in another field.

Sagala (2003) suggests two learning characteristics, namely: (1) in the learning process involves the maximum of students' mental processes, not only demanding students to listen and take notes, but it requires the activity of students in the process of thinking, (2) in the learning process, builds a communicative atmosphere by giving a lot of discussions which is directed to improve and enhance students' thinking ability, that can help students to acquire the knowledge of their own construction. While in the relation to the study of mathematics, Nickson (1992) suggested that learning of mathematics is an effort to help students to construct the concepts or principles of mathematics on their own through a process of internalization, so the concept or principle was rebuilt.

The process of construct the mathematical concepts or principles cannot be separated from the process of mathematical thinking which is a cognitive activity, while on the other side of human cognitive activities can only take place within the social and cultural environment. According to Vygotsky, all high-level cognitive work in humans has its origins in the social interactions of every individual in a specific cultural context (Bruming et al, 1995). Whereas on every teaching and learning activities required interaction, the interaction between students and another student, student interaction with the teacher and also student interaction with other learning tools.

The exposure above illustrates that the activity of learning mathematics cannot be discharged by the cultural background of students in the interactions of mathematics learning, and thus required an effort to assess the socio-cultural background of students in the interactions of teaching and learning activities based on local cultural background. 


\section{Review Of Literatures}

Siri' as the core culture of the Bugis-Makassar is a view of life that aims to enhance the dignity, the prestige, and self-esteem, both as individuals and as social beings. While pacce'/pesse' is a form of solidarity to the suffering of others. This implies that siri' and pacce' are inseparable of the human beings, containing difference ethical between humans and animals.

As the human beings, it contains the noble values that guide in life, both in interacting with fellow humans, interact with other creatures, and interact with themselves and in their relation to God. For example the Bugis expression that cited by Abidin (1983) states "naia riasengnge' to warani mapperengnge'. Narekko moloio roppo-roppo ri laommu, rewe'ko paimeng sappa laleng muolai" (a courageous person is strong and sturdy to survive. If you are facing heavy odds that you cannot go through or overcome, come to think of the way or ways to pass it). This expression contains the value of humanity, in which everyone is expected to have the courage to go through life and firmness in attitude and always uses their mind in any problems that they face.

The concept of siri' is the core culture of the Bugis-Makassar. Abidin grouped it into two parts, namely siri 'masiri' and siri 'ripakasiri'. In the concept of siri 'masiri' contains the spirit to always succeed in doing a job that can be worth to the person that concerned and also be worth to the surrounding community. In addition, it is also continues to provide unyielding spirit of life in the face of any situation. This is reflected in the principle of the sailors of Bugis Makassar, which reads "pura ba'bara sompe'ku, pura tangkisi' gulikku, ulebbireng telleng na toalie" (When I already developed my screen, my steering had been radiated, then it is better sinking then back in the low tide).

Those principle is always encouraging to work as closely as possible with a consideration so that they can succeed in the workplace. In addition, this principle also provides opportunities for the development of creativity. The feel of siri 'masiri' embedded in the soul of a citizen of Bugis-Makassar to never give up in the face of any situation that is extremely dangerous, providing a challenge to think and be creative in order to succeed in life.

The second concept is siri' ripakasari' which is a manifestation of the act to defend the honor for the sake siri' in society. Siri 'ripakasiri' appears in a person when he is humiliated in public. Within the people of Bugis-Makassar is always an ingrained sense of siri', so that when he is humiliated in public, they are usually willing to die to fight to uphold his siri' (upholding dignity). Therefore, in interacting with the people of BugisMakassar, senses of their siri 'ripakasari' need to be maintained.

According to the explanation above, then one of the things that need to be considered in the learning of mathematics to students with ethnic backgrounds of Bugis-Makassar is always giving spirit and motivation to work and also give a description of the success of their ancestors in the face of all the circumstances, including the persistence of the sailors of Bugis -Makassar in sailing the ocean. In addition, it should be noted that siri' ripakasiri' of the students did not rise. It is because if their siri 'masiri' is raised then the students will be insubordination. This defiance can be either physical resistance or can also be a reluctance to follow the lesson.

The rise of siri 'ripakasiri' on students can disrupt the concentration of students in learning process. This occurs because of the disruption of brain function, so that the information obtained by the students cannot be transmitted to the brain. Therefore, one way for the creation of a conductive atmosphere for children to make the student brain works as well so it can absorb the information properly is to avoid the rise of siri 'ripakasisri of the students.

The concept that closely to siri' is a concept of pacce' (Makassar) / pesse' (Bugis). It contains a high solidarity as an expression of fraternity, both of ethnic Bugis-Makassar and fraternity with other ethnic groups. The spirit of brotherhood of the people of Bugis-Makassar is very high. When he expressed brothers with someone even if that person is no kinship with him, so he was willing to die in defense of his brother.

Pacce '/ passe' is embodied the spirit of sipakatau, which is a spirit of mutual respect for fellow human beings. Besides that, the ethnic of Makassar known the spirit of sibatang abbulo, which is the spirit of cooperation and mutual help as human beings. Both of embodiment of pacce '/ pesse', sipakatau and also abbulo sibatang are not just working together and helping each other, but it contains the spirit of mutual suffering, a feeling of camaraderie, and being happy together.

This concept illustrates that people of Bugis-Makassar have a high spirit of cooperation in solving problems. In learning of mathematics, this spirit can be used as a foundation in the study together with the principle of mutual help among members in the group, so the failure and success in the group felt by all of the group members.

The concept of siri' and pacce' / pesse' which is often called the dual concept of Bugis-Makassar culture is giving the meaning of the relevance for compassion amongst people. The Compassion in human life of Bugis-Makassar is not too hard in the face off and not be too soft. As lontara phrase cited by Abidin (1999), which says "...janganlah bersikap terlalu manis, sebab engkau akan ditelan bulat-bulat. Jangan juga bersikap terlalu pahit, sebab engkau akan dimuntahkan ...". This phrase is an adage which implies that the people of 
Bugis-Makassar should not be treated too soft because they will be playing. They also should not be treated too rough and hard, because they will hate and fight. This compassion can be realized by providing assistance to students when needed.

The study above illustrates some of the principles that need to be considered in mathematics learning based on the culture of Bugis-Makassar. The principles are as follows:

1. The teacher tried to create a conducive atmosphere for students, so siri 'ripakasiri' does not appear in the student.

2. Teachers try to raise siri' masiri' $^{\prime}$ in students itself as an effort to raise the motivation of students to excel.

3. Realize the principle of abbulo sibatang in the models of the group task. In a group, the students are expected to help each other and feel the importance of each member's presence and cooperation for mutual benefit. In addition, in the group each student has an individual responsibility for the group's success.

4. The group leader is selected from one of the members who have more ability than the other members of that group so leaders also act as peer tutors.

5. Generate the compassion of students as a form of sipakatau through the provision of assistance to students both individually and in groups. In addition, a form of affection is also given in the form of awards to students who successfully and motivate students who have not succeeded.

6. The Assessment conducted on all student activities, both individually and in groups.

The mathematics learning that takes into these principles is expected to enhance the spirit of the learning process so students can improve their academic achievement, foster a positive attitude towards mathematics as well as foster a spirit of cooperation and mutual help with the others in their life. Thus the goal of learning mathematics, which is based on cognitive abilities and affective abilities expected to be achieved.

\section{The Field of Research}

\section{The Research Methods}

This research is tended of interdisciplinary between mathematics education and the humanities. It is a qualitative descriptive with emphasis on the exploration of the local cultural values of the learning process.

\section{The Subject of This Research}

The subjects of this research are the elementary school students in South Sulawesi, which has a local ethnic background of Bugis Makassar. Therefore, the area of South Sulawesi which allows the ethnic contained, then select one school in Makassar that has students which are their ethnic is generally Bugis Makassar.

\section{The Focus of This Research}

This study focused on the interactions of mathematics teaching and learning activities. The interaction between students and students and also the interaction between students and teachers. Thus allowing the observed values of the local culture of Bugis-Makassar that is involved at the time of interaction.

\section{The Research Instruments}

The data collected by observation with anecdotal records. The anecdotal technique is a recording made freely. Everything that is deemed to be noted in the paper without specific format. Thus, each time after making observations the date is already collected.

The steps that being taken in the implementation of the research is as follows.

1. Determine the subject of research

2. Collecting data using observation sheet form of anecdotal records.

3. Managing and organizing the data that has been collected and analyzed it.

4. Interpreting the results of the analysis for the conclusion / solution of the problem in this study.

\section{Data analysis technique}

Data collected through anecdotal records then analyzed by rearranging the contents of those records that are arranged systematically, comparing one with the other, then categorize into a particular group.

\section{Findings And Discussio}

The Interaction among students is the communication that occurs between students and neither other students in teaching and learning activities, both of when students learn individual nor group learning in the classroom. The data collected is focused on the involvement of local cultural values of Bugis Makassar when the interaction takes place.

Based on observations using anecdotal notes are described as follows. 
1. Students who have the ability on the average have a tendency to provide assistance to students whose abilities below. In this case the student has the high average of ability show compassion to students is lacking. Thus empathy shown in these interactions is a manifestation of the cultural values of local Bugis Makassar, a value of pacce '/ asse-bua bua. So it can be said that the value of pacce '/ asse-bua bua played a role in the interaction among students.

2. When the teacher gives exercises to be done in front of the class, the students showed enthusiasm to compete the task. This shows that the competitive spirit to achieve success appear on students. Thus the culture to maintain self-esteem as the embodiment of siri' values involved in the interaction among students.

\section{The Values of Local Culture in Interactions between Students and Teachers}

The student interaction with teachers that occurs in the classroom which is the focus of observation is the involvement of local cultural values of Bugis Makassar when teachers teach and guide students. From the observation using anecdotal records obtained as follows.

1. When teachers start the lesson, noted that teachers give a motivation for several times to make the students regard the explanation of teachers so that students can understand the explanation, giving a spirit and motivation to the students to make the data show the good learning outcomes. This shows that teachers are always trying to motivate students to succeed as an embodiment of value of siri masiri students

2. When the teacher gives an exercise to be tackled, teachers try to monitor students' work and sought to educate students who do not understand the task. This suggests that teacher trying to make sense of affection for the students. Compassion is a manifestation of the value of asse bua-bua.

Siri' and Pacce' is the core of the local cultural values of Bugis Makassar, it is a value that alive and thriving in the midst of the Bugis-Makassar. That is not only true in the interaction in the community, but also still be there when there is interaction in learning.

Abdullah (1985) argued that the concept of Siri' which is a live view of the people of Bugis Makassar, is the soul and spirit of every individual in the community. This concept is reflected in the pattern of behaviour, in the social system and the pattern of thinking.

This suggests that the expression people of Bugis Makassar has a soul and passion for being the best, the spirit of achievement transform herself so prices do not fall and contaminated in the community. In relation to the learning process, the concept of Siri' provides each student the meaning of their effort to always be the best, the teacher will always try to encourage students to make their students achieve something. This concept will be a motivation for students from the Bugis-Makassar to make a good achievement. The motivation provided by the teacher in the findings of this study are actually part of the concept of the Siri' itself, the Siri' masiri', which is containing the spirit to always succeed in doing a job that can be the benefit to the person that concerned and be the benefit to the surrounding community.

In addition, this concept also continues to provide unyielding spirit of life in the face of any situation. This is reflected in the principle of the sailors of Bugis Makassar, which says "pura ba'bara sompe'ku, pura tangkisi' gulikku, ulebbireng telleng na toalie" (When I already developed my screen, my steering had been radiated, then it is better sinking then back in the low tide).

The principle is always encouraging to work as closely as possible with consideration so that they can succeed in the workplace. In addition, this principle also provides opportunities for the development of creativity. The feel of siri 'masiri' embedded in the soul of people of Bugis-Makassar to never give up in the face of any situation that is extremely dangerous, providing a challenge to think and be creative in order to succeed in life.

The concept of siri' masiri' which was engraved in the people of Bugis Makassar, reflected in the findings of this study that showing the interaction of teachers and students, the teachers constantly motivate their students to be the best, as well as the interaction between students and students, in this case, the students are always racing to be the best.

The other findings in this study showed the involvement of pacce value in the interaction between teacher and students and also the student interaction with students. The value of Pacce is reflected among the student solidarity and the teacher assistance given to students who are having trouble. Students who have an academic ability at the top tend to help their friends who have difficulties. This is a realization of the value of pacce or sense of solidarity. Abdullah (1985) says that pacce contains a pledge or a promise between the group members who are struggling to live overseas or in the village itself. Further stated pace is an element of solidarity to unite attitudes and behaviour patterns of a group. They willingly suffer together, to struggle together, to enjoy the results together to defend the honour together and it is no exaggeration to say that they would die together.

Thus in the interactions of mathematics teaching and learning activities, the main value of Bugis Makassar culture, is always reflected in the pattern of interaction between students and teachers and the 
interaction between students and students. Both of main values is actually a human life of dual concepts of Bugis Makassar. As a stated by Andaya (Abdullah, 1985) Pacce' and Siri' are twin concepts that define the individual Bugis-Makassar. Maintaining a balance between shame and self-esteem as it is understood in siri' and nurture an awareness bear, merciful on pain and suffering of every member of society as demonstrated in an understanding of pacce, that is required of a people of Bugis Makassar.

\section{A. Conclusions}

\section{Conclusions And Recommendations}

The conclusions that can be drawn from this study are as follows.

1. The sense of siri 'masiri' always appears on students which are realized in the effort to be the best in his community. In this case, the student is trying to show the best performance in learning process.

2. The students in interacting with fellow students are always trying to create a sense of compassion for fellow students. This is shown by giving assistance to fellow students. It means that the local culture values of pacce '/ asse-bua bua have remained with the student.

3. The compassion on teachers themselves is constantly shown to students by a way of guiding and directing students to find the good things to the students.

\section{B. Recomendations}

Based on the results and findings above that obtained in this study, there are some suggestions or recommendations as follows.

1. Teachers should strive escort students to excel as a realization of local cultural values of siri 'masiri'.

2. Teachers should always guide the students so that the students who are good or students who have the good capacity on average help of other students, as an embodiment of cultural values of pacce / Passe-bua bua.

3 . Teachers are expected to continue to provide appropriate assistance to students as a realization of affection.

\section{References}

[1]. Abdullah, Hamid.,1985., Manusia Bugis Makassar. Jakarta: Indti Idayu Press.

[2]. _.., 1990., Reaktualisasi Etos Budaya Manusia Bugis. Solo: Ramadhani

[3]. Abidin, Andi Zainal., 1983. Persepsi Orang Bugis Makassar tentang Hukum, Negara dan Dunia Luar. Bandung: Penerbit Alumni.

[4]. Atweh, Bleicher \& Cooper, 1998., The Construction of the Social Contex of Mathematics Classrooms: A Sosiolinguitics Analysis. Journal for Research in Mathematics Education. Volume 29, Number 1, January 1998 USA: NCTM, Inc

[5]. Cobb, Wood, \& Yackel,1991., Small Group Interaction as A Source of Learning Opportunities in Second-Grade Mathematics. Journal for Research in Mathematics Education. Volume 22, Number 5, November 1991 USA: NCTM, Inc

[6]. Marzuki, Laica, 1995., Siri' Bagian Kesadaran Hukum Rakyat Bugis-Makassar. Makassar: Hasanuddin University Press

[7]. Nickson, Marilyn. 1992., The Culture of the Mathematics Classroom: An Uncknown Quantity. Handbook of Research on Mathematics Teaching and Learning (editor Douglass and Grouws). New York: Macmillan Publishing Company

[8]. Pelras, Christian., 2006., Manusia Bugis. Jakarta: Yayasan Adikarya

[9]. Sagala, Syaiful, 2003., Konsep dan Makna Pembelajaran. Bandung: Alfabeta

[10]. Soedjadi, R, 1999/2000. Kiat Pendidikan Matematika di Indonesia. Jakarta: Dirjen Dikti Depdikbud.

[11]. Susilo, Frans, 1998., "Matematika yang Manusiawi" dalam Sumaji, dkk. Pendidikan Sains yang Humanistis.., Penerbit Kanisius dan Universitas Sanata Dharma, Yogyakarta. 